\title{
研究課題別中間評価結果
}

1. 研究課題名： 超伝導量子ビットを用いた極限量子センシング

2. 研究代表者：齊藤 志郎 （日本電信電話（株） NTT 物性科学基礎研究所 主幹研究員・特別研 究員)

\section{3. 中間評価結果}

本課題は、量子情報処理技術の発展とともに格段な進歩を遂げた超伝導磁束量子ビットをセンサと して応用し、「量子限界」に到達する高感度・高空間分解能磁場センサを開発することを目標として いる。

これまでに、磁束量子ビットを用いて世界トップレベルの高感度・高空間分解能な電子スピン共鳴 (ESR) 測定を実現している。具体的にはYSO 結晶中のエルビウム電子スピンを測定し、物質パラメータ を同定、固体物性評価に有効であることを実証している。さらに、本測定系は検出器と読み出し回路 から構成されているが、検出器を超伝導量子干渉計から磁束量子ビットに改良し、読み出し回路を高 速化することにより、本課題開始当時と比較し感度を 4 桁向上し、更に検出体積も劇的に改善してい る。論文など成果の発表も順調であり、計画通りに進捗している。すでに、長寿命磁束量子ビットの 開発にも成功しており、単一電子スピン検出が期待される。単一電子スピン検出は量子センシングの みならず、量子メモリや量子トランスデューサへの応用が可能であり、量子情報技術の発展に資する 成果と成り得る。科学技術の進展に貢献する優れた基礎研究が行われており、高く評価できる。今後 は、生体試料検出やセンサのアレイ化など新しいセンサ応用への進展も推進していただきたい。 